\title{
INTERPROFESIONAL COLLABORATIVE PRACTICE IN HEALTHCARE OF LOW-BIRTH-WEIGHT CASES
}

\author{
Umu Faizah, Sulistyaningsih \\ Universitas ‘Aisyiyah Yogyakarta
}

\begin{abstract}
Background: Inter-professional health care providers play an essential role in the treatment of Low Birth Weight (LBW) cases. Collaboration between doctors, nurses, midwives and social service providers is significant for the care of LBW. This study aimed to find out the role and barriers of inter-professional health practice collaboration in LBW care cases.

Subjects and Method: A scoping review was conducted by selecting published articles years 2004-2019, from PubMed, EBSCO, Willey, Science Direct databases. The inclusion criteria were full text and using English or Indonesian language. Keywords used low birth weight, delay of referral, health workers, and inter-professional collaboration. The data were analyzed by PRISMA flow diagram.

Results: 9 articles were selected from 2,407. There were 2 main issues related to low birth weight management, including role and barrier of inter-professional collaboration. Common barriers to inter-professional collaboration were lack of knowledge, health personnel abstinence, delay of referral, and poor access to health service.

Conclusion: Role and low barrier of inter-professional collaboration are essential to provide good LBW management.
\end{abstract}

Keywords: inter-professional collaboration, barriers, role, low birth weight

\section{Correspondence:}

Umu Faizah. Universitas 'Aisyiyah Yogyakarta. Jl. Ringroad Barat No.63, Mlangi Nogotirto, Gamping, Area Sawah, Nogotirto, Gamping, Sleman district, Yogyakarta 55592. Email:

aiezahfarizi300916@gmail.com Mobile: 081217831458

The $7^{\text {th }}$ International Conference on Public Health

Solo, Indonesia, November 18-19, 2020 | 217 https://doi.org/10.26911/the6thicph.03.37 